\title{
INCOME DIVERSIFICATION OF ESTATE SECTOR IN SRI LANKA
}

\author{
Dharmadasa, R.A.P.I.S. and Polkotuwa, P.W.T.P. \\ Uva Wellassa University \\ sdharmadasa@gmail.com, thilini.poorni@gmail.com
}

\begin{abstract}
This study aims to identifying determinants of income diversification at household level in Sri Lankan estate sector. Analysis builds on data of Household Income and Expenditure Survey 2009/2010 conducted by Department of Census and Statistics of Sri Lanka. The data set covered 1736 households in Sri Lankan estate sector. Herfindhal Index was applied to calculate income diversification at household level and Censored Tobit model was used to identify the determinants of income diversification. The econometric analysis shows that gender and age of the household head, household size, ownership of agricultural land, number of workers above 15 years old and availability of migrants in a household have significantly contributed to the performance of income diversification. Further study indicates that migrants of estate household play a critical role in non estate income. All in all, the study clearly depicts that income diversification has become one of the important strategies of income improvement in estate households.
\end{abstract}

Keywords: Income, Diversification, Households

\section{INTRODUCTION}

Diversification is referred to a process by which the presence of multiple income sources is created in households (Nghiem, 2010). Most of households are willing to increase their household income to raise their wealth. Hence, they easily adopt income diversification activities. On-farm diversification and Non-farm diversification are the key elements in farm household diversification. Farming as a livelihood activity is associated with high amount of risk. Farm income fluctuates with various factors such as climatic change, pest and disease problems, price variations, policy changes etc. Therefore, households are pushed into income diversification. Most of the researches point out that participation in income diversification activities and level of income derived are influenced by human capital related variables such as gender, age of household head, number of economically active family members, education level, household size etc.(Bartoliniet al., 2014, Wanyama et al., 2010Agyeman et al., 2014, Demissie and Legesse, 2013) and also they describe income diversification as commercialization process and value addition process. 


\section{THE ESTATE INCOME} D I V E R S I F I C A T I O N SETTING

When we move to the Sri Lankan estate sector, the estate sector in Sri Lanka has a history expanding almost 150 years, as Sri Lanka became a British colony in 1815 . Tea, Rubber, Coconut (plantation agriculture) were introduced during this British colonial period. After introducing plantation agriculture, Sri Lanka was categorized into three main economic sectors. Those are Urban, rural and Estate sectors. The estate sector was developed as self - sufficient community structure with little contribution into national socio economy. Labour force of plantation sector was imported from south India (Gunetillekeetal., 2008). After independence considerable changes occurred in the estate sector. The position of plantation crops in the national economy has fallen because ownership has moved from foreign to national. Moreover, socio economic status of estate sector is considerably lower than those in other two sectors. Poverty is a big problem in estate sector. Low levels of education, poor decision making skills, and poor infrastructure are the reasons for lower socio economic status of estate sector (Semasinghe, 2014). As a result of these factors, household members became interested in income diversification strategies to improve their livelihood portfolio (World Bank 2007). Estate households started to earn their income from employment, agricultural activities, nonJournal of Business Studies agricultural activities and a little contribution of remittance, transfers and other income generating activities such as pensions, rents, income in kind. However, less market access, poor infrastructure, low levels of education are the major barriers for income diversification in estate sector. At present, there is a trend in young generation of estate sector to seek alternative income sources outside the estate to solve immediate household needs; food, shelter, healthcare, fulfillment of children's needs.

More than $40 \%$ of estate households earn their income from wage employment inside the estates (Atukorala et al., 2010). Uncertain factors such as weather and market conditions directly affect the income in estate households because these uncertain factors results in variable returns in estate households. Income variability is a problem that households face. This is the main reason for high poverty in this sector. Estate households have a significant challenge to reduce poverty. The most popular as well as the most successful method of coping as well as moving out of poverty is by diversifying income in the household livelihood portfolio. Therefore, as result of diversification strategies, their lifestyles started change. As a result, income diversification has impacted on estate sector as well as on household members. And also income diversification gives opportunity to avoid the income variability of the estate households. Therefore, it is important if the factors that determine the income diversification could be identified. A study 28 
of this nature would provide us to think of what policy instrument would be implemented to promote diversification strategies. It is fact that interest of youth to engage in estate work is losing. They tend not to work in the estates. If they stay in the estate they are supposed to work in estate. Therefore, they contribute to the total household income. If they do not work in the estates, their contribution to total household income might be lost. However, if they are employed in elsewhere or engaged in nonestate activities, non-farm activities or other agricultural activities, they would contribute to the household development. If that is so, what factors of the household members affect the decision to engage in some other income generating activities other than estate income would be worthwhile to study. On the other hand, the estate worker population is aging. Therefore, their contribution to estate would be reducing. As a result of these, they may earn poor income from estates and the lost income to the households will have to be compensated. Therefore, income diversification provides a better solution to the households in this regard.

\section{INCOME DIVERSIFI- CATION AND ITS DETERMINANTS; A REVIEW OF LITERATURE}

Income diversification is defined as a process in which rural households increase their employment and income from the non- farm sector(Barrett and Reardon, 2000). Income Diversification is a process in which multiple income sources are created by rural households (Minotet al.,2006). Therefore, income diversification is an ideal solution to improve household income. Researchers have identified a variety of factors that may explain income diversification (Barrett and Reardon, 2000, Ibekwe et al., 2010, Escobal, 2001). The theoretical discussions of those researches point out two categories drives of income diversification. Those are push factors and pull factors. The "Push factors" terminology refers external factors which causes the fluctuation of farm income such as weather conditions, policy changes etc. The "Pull factors" refers growth opportunities in term of household income (Barrett et al.,2001).Household income diversification strategy is affected by push factors rather than pull factors. Moreover, pull factors play complementary roles for push factors in facilitating income diversification (Barrett et al., 2001, Khai and Danh, 2015). Main advantages of income diversification are risk reduction, reducing poverty, meeting consumption needs and increasing human welfare etc. (Agyeman et al., 2014, Amanze et al., 2015, Bartolini et al., 2014). On farm diversification and Nonfarm diversification are the common diversification strategies in the world. Recent studies indicate the rural households in Africa increasingly diversify their income sources by combining farm and non farm activities to sustain their livelihood (Barettet al., 2001, Sarah, 2012). 
Participation of non- farm activities are influenced by individual or household specific factors as well as social, economic and environment factors. These factors play a critical role in household wealth, private and public assets endowment etc. (Escobal, 2001). Households are pulled into the nonfarm activities because non -farm employment are higher and less risky than in agriculture activities (Ibekwe et al., 2010). On the other hand, when farming is less profitable and a market failure, many households are pushed into non farm activities.

The age of the household head is a main determinant of income diversification as decision making process of household level depends on age of the household head. He/ she has more bargaining power over the decision making process. There are various ideas regarding the relationship between age of the household head and income diversification. According to Agyeman et al.,(2014), when age of head of farm household increases, they less diversify their income because of lack of physical strength and financial resources to add on to their farm or non-farm activities since majority of these activities are labour intensive. Gender of the household head is a significant factor for income diversification. (Bartolini et al., 2014). It is a positive determinant of participating non- farm activities. Most of the previous literature points out male head households are able to participate in non farm activities compared to female head households. Education is a one of the most Journal of Business Studies important determinant of income diversification. Many recent studies indicate that the number of years of education of household head is positively influenced on income diversification. Thus having some educational levels attainment facilitates entry into high paying jobs (Agyeman et al., 2014, Demissie and Legesse 2013). So is the case with education level of other household members as well.

\section{DATA}

Data was mainly gathered from Household Income and Expenditure Survey (HIES) of 2009/2010 conducted by the Department of Census and Statistics under the national household survey program of Sri Lanka. HIES covered around 20000 housing units throughout the country. The data include 54307 rural household members, 23346 urban household members and 7790 estate household members. This study employs only the data that belong to 7790 estate household members of 1736 households. Estate households earn their income from wage and salaries, agriculture activities with seasonal crops, agriculture activities with non- seasonal crops, non- agriculture activities, Other regular cash receipts include Pensions, Dividends, Rents etc., Irregular gain or windfall income and Income in kind. For studying purpose data was classified into five major income sources. Those were employment income, agriculture income, non-agriculture income, transfers and remittance and other income source. 


\section{ANALYTICAL FRAME WORK}

\subsection{Herfindhal Diversification Index}

Herfindhal Diversification Index is used to calculate the income diversification in household level. The HDI is based on the Herfindhal index (HI)

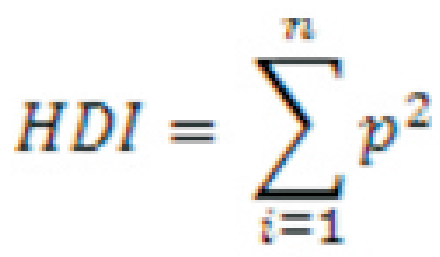

pis proportion of each income source on total household income. HDI cannot be below zero or above one.

\subsection{Tobit Regression Analysis}

A Tobit regression model is used to analyze the determinants of income diversification.

$$
S^{*}=\beta_{0}+\beta_{1} X_{1}+\beta_{2} X_{2}+\ldots+\beta_{n} X_{n}+u
$$

$S=\left\{\begin{array}{l}0 \text { if } S^{*} \leq 0 \\ 1 \text { if } S^{*} \geq 1\end{array}\right.$

$\mathrm{X}_{1}, \mathrm{X}_{2} \ldots, \mathrm{X}_{\mathrm{n}}$ denote independent variables $S^{*}$ is a latent variable indicating desired Herfindahl index while $\mathrm{S}$ is the observed Herifindahl Index.

Above $\mathrm{u}$ is an error term which is assumed to follow a standard normal distribution. In this study, some estate households have zero income shares due to absence in participation any income generating source. Corresponding to this situation gives a zero value for the dependent variable (censored). Therefore, Censored Tobit regression was used as estimation method for this study.

Table 1:Model Specification of Determinants

\begin{tabular}{ll}
\hline Variable & Measurement \\
\hline $\begin{array}{l}\text { Dependent Variable } \\
\text { Household's Income Diversification }\end{array}$ & \\
Independent Variables & Herfindahl Index \\
Gender of Household Head (1=males, & \\
$0=$ females & Dummy \\
Age of Household Head & Years \\
Education level of Household head & Average Schooling \\
Housing Structure (1= line rooms, $0=$ Otherwise) $)$ & Years \\
Household Size & Number \\
Ownership of Agricultural land $(1=$ yes, $0=$ No) & Dummy \\
Number of dependents & Number \\
Availability of Migrant members $(1=$ yes, $0=$ No $)$ & Dummy \\
\hline Journal of Business Studies 31 &
\end{tabular}


Number of Workers above 15 years

Number of Members over age 15 with above

$\mathrm{A} / \mathrm{L}$ or with $\mathrm{A} / \mathrm{L}$ education

Number

Number of Members over age 15 with O/L

education

Number of Members over age 15 with 6-10

years education

Number

Number

Number of members over age 15 with $0-5$ years education

Number

Number

Source: Household Income and Expenditure Survey 2009/10

\section{RESULT AND DISCUSSION}

\subsection{Summary Statistics}

According to the results of table 2, most of household heads are 49 years old but minimum age is 18 years and maximum age is 92 years. When we consider about the average household size of the sample, it is 4 members per household. Maximum household size is 14 members and minimum household size is 1 member. A Number of dependents in a household are distributed from 0 to 11 range.
Education Level of household members (above 15 years old) is categorized into three categories. Those are Primary education, Secondary education, Ordinary Level education and Advanced level or above advance level qualification. A number of $\mathrm{A} / \mathrm{L}$ or above $\mathrm{A} / \mathrm{L}$ qualified member, Primary educated members and Secondary educated members in a household distributed from 0 to 6 . A number of grade 6 to 10 years educated members are in a household distributed from 0 to 4 .

Table 2: Summary Statistics of Independent Variables

\begin{tabular}{lcclll}
\hline Variable & Obs & Mean & $\begin{array}{l}\text { Std. } \\
\text { Dev. }\end{array}$ & Min & Max \\
\hline Gender of Household Head & 1736 & 0.759 & 0.427 & 0 & 1 \\
Age of Household Head & 1736 & 49.50 & 13.49 & 18 & 92 \\
Education level of Household & 1736 & 4.763 & 3.577 & 0 & 17 \\
head & & & & & \\
Housing Structure & 1736 & 0.615 & 0.487 & 0 & 1 \\
Household Size & 1736 & 4.099 & 1.791 & 1 & 14 \\
Ownership of Agricultural land & 1736 & 0.348 & 0.476 & 0 & 1 \\
$\quad$ Number of dependents & 1736 & 1.906 & 1.848 & 0 & 11 \\
\hline Journal of Business Studies & 32 & & & & Issue II - 2016
\end{tabular}




\begin{tabular}{lccccc}
$\begin{array}{l}\text { Availability of Migrant members } \\
\text { Number of Workers above 15 }\end{array}$ & 1736 & 1.745 & 0.959 & 0 & 6 \\
$\begin{array}{l}\text { years } \\
\begin{array}{l}\text { Number of Members over age 15 } \\
\text { with above A/L or with A/L }\end{array}\end{array}$ & 1736 & 0.267 & 0.442 & 0 & 1 \\
$\begin{array}{l}\text { education } \\
\text { Number of Members over age 15 }\end{array}$ & 1736 & 0.09 & 0.523 & 0 & 6 \\
$\begin{array}{l}\text { with O/L education } \\
\text { Number of Members over age 15 }\end{array}$ & 1736 & 0.62 & 0.484 & 0 & 6 \\
$\begin{array}{l}\text { with 6-10 years education } \\
\text { Number of members over age 15 } \\
\text { with 0-5 years education }\end{array}$ & 1736 & 0.803 & 0.397 & 0 & 6 \\
\hline
\end{tabular}

Source: Household Income and Expenditure Survey 2009/10

6.2 Det e rminants of Income Diversification; Results of Tobit regression

The results of regression analysis conducted to estimate the determinants of income diversification are presented in table 3. Data set was covered around 1736 households. It also shows the statistical significance of the coefficient at $1 \%, 5 \%$ and $10 \%$ levels. The results indicate that independent variables such as Gender of household head, Age of household head, Household size, Dependents of households, Present of migrant members, Availability of agricultural land and Number of workers (above 15 years old) are the factors which were significant in determining the level of income diversification among the estate sector household sample in Sri Lanka.

Table 3:Tobit Parameter Estimates of Determinants of Estate Household Income Diversification

\begin{tabular}{lll}
\hline Variables & Coefficient & P value \\
\hline Gender of Household Head & -0.0837 & $0.002 * * *$ \\
Age of Household Head & 0.0029 & $0.002 * * *$ \\
Education Level of Household Head & 0.0003 & 0.449 \\
Ownership of Agricultural Land & 0.1369 & $0.000 * * *$ \\
Household Size & 0.2571 & $0.004 * * *$ \\
Housing Structure & 0.0222 & 0.372 \\
Number of Dependents & -0.0843 & $0.000^{* * *}$ \\
\hline Journal of Business Studies & & Issue II - 2016
\end{tabular}


Number of Workers above 15 years old

$-0.0304 \quad 0.038 * *$

Availability of Migrants members

$0.1827 \quad 0.000 * * *$

Number of Members over age 15 with $\mathrm{A} / \mathrm{L}$ or Above

0.0196

0.444

$\mathrm{A} / \mathrm{L}$ education

Number of Members over age 15 with $\mathrm{O} / \mathrm{L}$ education

0.0343

0.265

Number of Members over age 15 with 6-10

0.0146

0.333

Number of Members over age 15 with $0-5$ years

$-0.0021$

0.905

education

\begin{tabular}{lll}
\hline Number of Obs. $=1736$ & LR Chi $^{2}(13)$ & $=178.42$ \\
Prob $>\mathrm{Chi}^{2} \quad=0.0000$ & Psudo $\mathrm{R}^{2}$ & $=0.0872$ \\
Log likelihood $=-933.40804$ & & \\
994 - Left Censored Observations at herfindhal $<=0$ & & \\
743 - Uncensored Observations & \\
$\begin{array}{l}0 \\
\mathrm{P}^{*}<0.1 \quad \text { Right Censored Observations }\end{array}$ & \\
\hline
\end{tabular}

Source: Household Income and Fxnenditure Survev 2009/10

Gender of the household head is statistically significant at $1 \%$ significance level, but negatively associated with the likelihood of income diversification. These results interpret that female household heads are engaged in income diversification activities more than the male household heads. This finding implies a clear indication that females also have more decision making power over the income diversification and they tend not only to take care of the household work and being mostly involved in estate activities, but also they influence the diversification activities.Malek and Usami, (2009) point out that gender is an important for receipt of international remittancesand they further mention that most of female household heads diversify their income by using international remittances. Some economic researches states gender gap in education has decreased in most of developing countries, female heads generally have a lower level of education than male ones. They might also lack the connections needed to get access to highly paid employment outside the farm. Sometimes social norms regarding female labour force participation hinder women from entering labour market. In this situation they diversify their income from on farm activities (Vimfall, 2015). On the contrary, Dimissie and Legess (2013) mentioned male household heads diversify their income more than female household heads. Hence, they point out males have ability to pursue more lucrative income generating activities. Age of the household head is also significant. This implies that the likelihood of income diversification is high among older household heads, relative to young ones. Age of the household head is a good measurement for their experience. So they 
have experience of risks associated with estate wage employment. In this situation old household heads easily diversify their income than young household heads.

Household head's education level is insignificant but it has positive association with the likelihood of income diversification. Household heads with low level of education earn their income only from estate work while household heads with higher education level are more likely to diversify their income because their educational level facilitate entry into high payment jobs in government and private sector. These findings are similar to Ibekwe et al.,(2010) and Agyeman et al.,(2014). Household size is significant in $1 \%$ significance level. This is not surprising because every additional member living in a household contribute to increase the need of total household income, because their total consumption increases. Many studies have shown that rural households diversify their income by on farm activities due to the large household size (Barrett et al., 2001).

Housing structure is important parameter for income diversification as housing structure links with socio economic status of households. According to above finding (Table 3), housing structure is insignificant but it is positively associated with income diversification. Above results indicates people who are in line rooms diversify income more than those in other housing units (for example, single houses etc.). Most of line rooms have poor infrastructure such as lack of water, lack of drainage facilities, lack of toilet facilities etc. Poverty is a major problem in of estate workers living line rooms. People who are in line rooms are also interested in moving out of poverty. In this situation, they tend to diversify their income. Number of dependents in a household is highly significant at $1 \%$ significance level. Furthermore, number of dependents is negatively associated with income diversification i.e. if number of dependents is low in a household, it could be assumed that most of the household members are active members in the household. As a result, those members can join with various income generating activities.

Numbers of workers are significant at 5\% significance level. There is a negative relationship between number of workers (above 15 years) and income diversification. This is a surprising result but we can justify this negative relationship because majority of workers are estate workers. Therefore, when number of estate worker decreases, there is a high tendency to diversify the income. It implies that fewer number of workers are engaged in estate work, more will be to move on to non - agricultural activities. Availability of agricultural land is also totally significant with positive association. Availability of agricultural land is good opportunity for on farm diversification. Because ownership of agricultural land, motivate households to diversify their income by growing vegetables, cash crops and move on to 
livestock management. Bartolini et al.,(2014) point out in their study that land and production system have a significant effect on adoption of diversification. Large landholders may allow households to pursue non farm activities through earnings generated from the farm or by selling of land (Nghiem, 2010).Presence of migrant members in a household is highly significantly and positively associated with income diversification. Migrants in a household are important to gain remittances and transfers. Those members move out of estates and generate income from various activities. Some of them move out of the country for generating income (Overseas employment). Although migration and remittances positively affect to increase household income and wealth of estate households, migration of estate labour out of estates may have a negative impact on the estate production process as most of the activities undertaken in tea and rubber estates are highly labour intensive.

Number of Members with advanced level $(\mathrm{A} / \mathrm{L})$ and above $\mathrm{A} / \mathrm{L}$ education is insignificant but positively associated with income diversification. Literature also supports the fact that higher levels of education among household members have a positive effect on income diversification (Barrett and Reardon, 2001, Sarah, 2012). Number of households with ordinary level $(\mathrm{O} / \mathrm{L})$ education and $6 \quad 10$ years education also is not significant, but have a positive association with income diversification. It means increasing of education level causes Journal of Business Studies households to diversify their income towards non- farm activities(Ibekweet al., 2010 and Agyeman et al., 2014). Primary education is also insignificant and income diversification is negatively associated with primary education. This is due to the fact that less educated persons have a barrier to enter to highly qualified jobs.

\section{CONCLUSIONS}

Estate sector is a unique feature in the Sri Lankan economy and it contributes to earn foreign exchanges as one of the major exports in Sri Lanka. However, most of the estate people are poor and the sector is considered to be the poorest sector in Sri Lanka. Therefore, people in this sector tend to diversify income portfolio to get rid of their poverty. They diversify into different income generating activities such as growing vegetable crops and other cash crops, rearing livestock and working outside the estates. However, the working outside estates does not necessarily mean that it leads to higher earning. Internal and international migration has also become a significant strategy to diversify their income. Most of the young people who have moved away from estates in search of better opportunities work in capital city orin other cities and they do some ad hoc type jobs and work in garment factories (World Bank 2007). As it has become a norm among the estate workers that they tend towards income diversification activities, this paper attempted to explore the determinants of income diversification among estate 
households in Sri Lanka. Our results suggest that ownership of agriculture lands, presence of migrants in a household, number of dependents, gender and age of household head, household size and number of employed people in the households are the most important factors for income diversification. It also should be emphasized that income diversification is one of the best opportunities to move out of poverty and the impact of income diversification on estate poverty should be explored.

\section{RECOMMENDATIONS}

Based on above findings, it could be recommended that the land owners should be encouraged to practice on farm diversification strategies such as livestock management; growing vegetables etc. as it is a better pathway to ensure reduction of risk associated with estate employment and low wages. As young household heads have less ability to diversify income than old ones, awareness programs are essential for young household heads in order to stress the importance of diversification. It is also recommended that diversification strategies should be encouraged among estate households to uplift their living standards. Although the education level is not a significant factor in favor of diversification, the education facilities and access to other infrastructure facilities should be improved in order to harvest the fruit of income diversification. If human capital is improved through improving education facilities, the estate people would find better paying jobs outside the estates. Therefore, it may lead to reduce their poverty status as well. However, there must be a strategy to manage the estate when young people become educated and out-migrate in search of better opportunities as the estate management practices are highly labour intensive. The findings also suggest that female household heads tend more towards income diversification. This is an indication and their bargaining power within the household has increased and therefore, women should be empowered more towards diversification strategies and more studies towards this aspect are highly essential in the future. On the other hand studies related to impact of income diversification on poverty of estate sector is of great importance to see the real impact of income diversification. However, it should also be emphasized here that estate sector production process should be improved with a balanced management strategy of income diversification and estate sector production if the policy is to promote income diversification.

\section{REFERENCES}

Agyeman, B. A. S., Brempong, S. and Onumah, E. E. (2014). "Determinants of Income Diversification of Farm Households in the Western Region of Ghana", Quarterly Journal of International Agriculture, Vol. 53, pp. 55-72.

Amanze, J., Ezeh, C. and Okoronkwo, M. (2015). "Pattern of Income Diversification Strategies among 
Rural Farmers in Nnewi North Local Government Area of Anambra State",Journal of Economics and Sustainable Development, $\mathrm{Vol}$ 6, pp 109-116.

Atukorala, K,.. Pinnawala, S. K and Kamalarathnne, T. (2010). "The Plantation Sector in Transition, Research on the Up Country Plantation Sector in Sri Lanka", The Team Research, Department on Sociology, University of Peradeniya.

Barrett, C. B. and Reardon, T. (2000). "Asset, Activity, and Income Diversification Among African Agriculturalists: Some Practical Issues", [Online] Available at http://dx.doi.org/10.2139/ssrn.257344 [Accessed 25 Aug.2015].

Barrett, C. B., Reardon, T and Webb, P. (2001). "Non farm Income Diversification and Household Livelihood Strategies in Rural Africa: Concept, Dynamic and Policy Implications", Food Policy, Vol. 26, pp. 315-331.

Bartolini, F., Andreoli, M. and Brunori, G. (2014). "Explaining Determinants of the On-farm Diversification: Empirical Evidence from Tuscany Region", Bio-based and Applied Economics, Vol.3, pp. 137-157.

Demissie, A. and Legesse, B. (2013). "Determinants of Income Journal of Business Studies
Diversification Among Rural Households: The Case of Smallholder Farmers in Fedis District, Eastern Hararghe Zone, Ethiopia", Journal of Development and Agricultural Economics, Vol.5, pp. 120-128.

Department of Census and Statistics, (2011). Final Report, Household Income and Expenditure Survey - 2009/2010, Department of Census and Statistics, Ministry of Financial and Planning Sri Lanka. [Online] Available at www.statistics.gov.lk [Accessed 1 Sep. 2015]

Escobal, J. 2001. The determinants of nonfarm income diversification in rural Peru. World Development, Vol 29, pp 497-508.

Gunetilleke, N., Kuruppu, S. and Goonasekara, S. (2008). "The Estate Sector Dilemma:Tensions and Changes in the Tea and Rubber Plantation in Sri Lanka", Study Series No. 04, Centre of Poverty Analysis (CEPA), Colombo.

Ibekwe, U. S. E., Ohajianya, C.C., Orebiyi, J. S and Onyemauwa, C.S. (2010). "Determinants of Non Farm Income Among Farm Households in South East Nigeria", Academia Arena, Vol.2, No.8.

Jafferjiee , A. and Senanayake, D., (2014). "Poverty Reduction Strategy in Sri Lanka", Briefing Paper Series No. $3 \mathrm{~A}$. 
Centre for Poverty Analysis (CEPA), Colombo.

Khai, T. T., Danh, N. N. (2015). "Determinants of Income Diversification and its Effect on Household Income in Rural Vietna", School of Economics, University of Economics, Ho Chi Minh City, Vietnam

Malek, M. A. and Usami, K. (2009). "Determinants of Non- farm Income Diversification in Developing Village of Bangaladesh", American Journal of Economics and Business Administration, Vol. 1, No. 2, pp. 141149.

Minot, N., Epprecht, M., Anh, T.T.T. and Trung1, Q.T., (2006). "Income diversification and poverty in the Northern Uplands of Vietnam", Washington, D.C. International Food Policy Research Institute, Research Report,pp 145-149.

Nghiem, L. (2010). “Activity and Income Diversification: Trends, Determinants and Effects on Poverty Reduction. The Case of the Mekong River", International Institute of Social Studies of Erasmus University (ISS), [Online] Available at repub.eur.nl/pub /19240/Thesis_Nghiem.pdf [Accessed 5 Sep.2015].

Perera, K. D. D. (2010). "Sri Lankan Estate Sector Poverty Alleviation: What role can Microfinance Play?", Presented on Fourth Annual Research Forum, Sri Lanka Agriculture Economics Association, p.15.

Sarah, A. (2012). "Determinants of Rural Household Income Diversification in Senegal and Kenya", Lund University (Sweden), pp. 1-18.

Semasinghe, W.M. (2014). "Poverty incidence in Sri Lanka : Overview, Trends, Challenges and Opportunities", Humanities and Social Science,Vol. 2, No.5,pp. 132-138.

Vimefall, E. (2015). "Income Diversification among Female Headed farming households", Orebro University, School of Business, Orebro, Sweden, [Online] Available at http://www.diva-portal.org/ smash/record.jsf?pid=diva2:846169[ Accessed 27 Aug. 2015].

Wanyama, M., Mose, L., Odendo, M., Okuro, J., Owuor, G. and Mohammed, L. (2010). "Determinants of Income Diversification Strategies amongst Rural Households in Maize based Farming Systems of Kenya", African Journal of Food Science, Vol. 4, pp. 754-763.

World Bank (2007)."Sri Lanka Poverty Assessment: Engendering Growth with Equity: Opportunities and Challenges", World Bank, Washington D.C 